\title{
TEACHING STRATEGIES; PERCEPTION OF MEDICAL STUDENTS, USED IN BASIC SCIENCES YEARS
}

1. Associate Professor of Medicine Islam Medical College, Sialkot

2. Assistant Professor of Pathology Khawaja Muhammad Safdar Medical College, Sialkot.

3. $3^{\text {rd }}$ year MBBS CMH Lahore Medical College, Lahore.

Correspondence Address: Dr. Muhammad Asif Bhalli, Lt Col (R) House No: 24-B, Askari - 02, B Sialkot Cantt asifbhalli@yahoo.com

Article received on: 08/12/2015

Accepted for publication: 25/03/2016

Received after proof reading: 04/05/2016

\section{Dr. Muhammad Asif Bhalli', Dr. Abdul Sattar ${ }^{2}$, Midhat Asif ${ }^{3}$}

ABSTRACT... Objectives: To determine preferences and perceptions of medical students about teaching strategies in basic sciences years. Study design: Mixed method study. Place and Duration: Khawaja Muhammad Safdar Medical College, Sialkot, from March 2014 to July, 2014. Methodology: A total of 77 medical students of 3rd year MBBS were selected through non-probability convenient sampling for this study. A questionnaire to know about their preferences and comments about teaching strategies was distributed to the students. A focus group discussion was also carried out to know in depth opinion of students about different teaching strategies. Results: Mean age of the medical students was $22.75 \pm 1.05$ years. Twenty one (27.3\%) participants were males and $56(72.7 \%)$ females. Out of 77 students, 22 preferred interactive lectures; 16, small group discussion; 20 problem based learning, 10 preferred demonstration on models. Only 01 students preferred one-way lecture as the best teaching methodology.More female students (30.3\% vs $23.8 \%)$ preferred interactive lectures and more male (28.6\% vs $17.8 \%$ ) students preferred small group discussion as their teaching strategies. Conclusion: Majority preferred interactive lectures (28.57\%) and problem based learning $(25.98 \%)$ as teaching strategies. Aligning our teaching strategies with preferences of the medical students will improve learning and academics.

Key words: Instructional strategies, teaching strategies, lectures, interactive learning, problem based learning, active learning

Article Citation: Bhalli MA, Sattar A, Asif M. Teaching strategies; perception of medical students, used in basic sciences years. Professional Med J 2016;23(5):614619. DOI: 10.17957/TPMJ/16.3206

\section{INTRODUCTION}

In recent years, a great paradigm shift has been observed in the field of education in general and medical education in particular. New concepts and themes have come up in the field of medical education. Traditional teacher centered approach is gradually being replaced by a student centered learning. Teachers who conceive teaching as simple transmission of knowledge use content/ teacher centred approaches, and teachers who take teaching as facilitating learning use learner centred approaches. ${ }^{1}$

In our country majority of medical colleges are still using the traditional methods of instruction (lectures) where teachers talk and students listen passively. These methods are used despite the strong evidence that better learning is achieved by other methods of instruction.2,3 Best teaching strategies are those which makethe students active participants in the learning process. Teaching strategies refer to the methods, techniques and procedures a teacher uses during instruction to achieve desired learning objectives. Learning activities are teacher guided instructional tasks or assignments done or performed by the students. Teaching strategy does not in itself imply an active or passive instruction. A teacher may select a teaching strategy like a one way traditional lecture where students are required simply to listen (passive learning). Conversely a teacher may select problem based learning session where students are required to participate actively in the whole learning activity to learn different details and solve a certain problem. Teachers sometimes prefer to stay with lecture methods and other traditional teaching strategies rather than using active teaching techniques and strategies, reason being their fear of not covering the required educational content and their concern of losing 
control of proceedings in the class.

Researchers have consistently supported and demonstrated that students learn better if they are actively involved in the educational content they are being taught. ${ }^{4,5}$ Active learning is a process whereby students engage in activities, such as reading, writing, discussion, or problem solving that promote analysis, synthesis, and evaluation of educational content. Interactive lectures, class quiz, one best MCQs at beginning or end of lecture, clinical scenarios, problem-based learning, small group discussions, tutorials, patient based learning, demonstrations, clinical skills lab, bed side teaching and simulations, all are some approaches that promote active learning.

Teaching strategies in a society could be affected by many variables. ${ }^{6}$ Understanding the way students learn, helps in selection of the teaching strategies best suited to them. ${ }^{7}$

The aim of this study was to know the students' preferences of various teaching strategies used in basic sciences and their in-depth perception about these strategies.

\section{METHODOLOGY}

This mixed method study was conducted at Khawaja Muhammad Safdar Medical College, Sialkot from March 2014 to July 2014. Approval for this study was obtained from Institutional review board. Seventy seven (77) out of 95 medical students of 3rd year MBBS were selected through non-probability convenient sampling. All students, both male and female, who had appeared in the second professional university examination were included in the study and those students who had been relegated to this class because of failing supplementary university examination were excluded from the study. An informed consent was sought after a re-assurance that the data obtained will remain confidential and will not be shared with any administrative authority. The students were explained the purpose and aim of this study. The participants were given option to mention their names or otherwise on questionnaire. The participants were given 30 minutes to fill the questionnaire. Questionnaire was distributed to the participants to know their preferences for teaching strategies (instructional strategies) and teaching aids. All the students had appropriate exposure to all the teaching strategies like One-way lecture, interactive lectures, small group discussion (SGD), students presentation in tutorials, Problem based learning (PBL), demonstration on models and specimens (DMS), guest speakers and self-study. Student were required to select one out of nine teaching strategies they thought was best as far as learning was concerned.. They were also asked to select the best teaching aids out of six. Students were also asked to score every teaching strategy regarding its usefulness in learning on a 5 point Likert Scale from strongly agree (5) to strongly disagree (01). This Questionnaire also contained open ended questions asking the students suggestions, reasons and comments for liking or disliking any teaching strategy. After studying the comments and opinions written by the medical students in response to open ended questions, certain points needed further clarification and discussion. For this purpose a focus group discussion was carried out after 10 days with 15 students (8 females and 07 males) to further clarify their opinions and get better insight to the various aspects of different teaching methodologies. Students were selected through non-probability convenient sampling. Focus group discussion (FGD) involved $1^{\text {st }}$ and $2^{\text {nd }}$ researcher and it continued for 60 minutes. It was audio- recorded and transcribed later. Content analysis of the qualitative data obtained from comments of the students and FGD was carried out independently by the two researchers. Common themes and sub-themes (codes) were identified and any coding differences between two researchers were resolved through discussion and consensus.

Data was analysed by SPSS, version 20 . Frequency and percentages were calculated for categorical variables like gender, and teaching strategies and teaching aids. Mean and standard deviations were calculated for quantitative variables like age and Likert Scale scoring for 
teaching strategies.

\section{RESULTS}

Seventy seven (77) students participated in this study. Age of the participants ranged from 21 to 25 years with a mean of $22.75 \pm 1.05$ years. Twenty one $(27.3 \%)$ of the participants were males and $56(72.7 \%)$ were females.

In this study, students were asked to select the teaching strategy by which they learn the best. Detail of students' preferences for different teaching strategies is given in Table-l. Majority of the students chose interactive lectures (22, $28.57 \%)$, problem based learning $(20,25.98 \%)$ and small group discussions $(16,20.78 \%)$ as their preferred teaching strategies.

Students also showed their perception about usefulness of each strategy by scoring on a Likert Scale. Frequencies and percentages of responses for each strategy along with mean scores and standard deviations are given in Table: 02 . If we take strongly disagree and disagree as combined $(S D+D)$, then overwhelming majority $(71,92.2 \%)$ rejected one way lecture as the best teaching method while strongly supporting (Strongly Agree+Agree) interactive lectures (63, 81.9\%), SGD (67, 87.1\%), DMS (66, 85.5\%) and PBL (60, $78 \%)$. Further details are given in Table-II.

Medical students also wrote comments and reasons about their liking of any particular teaching methodology and also gave suggestions. Comments were read together with transcribed verbatim of FGD and common themes from both sources were identified and grouped together in Table-III under perceptions (positive and negative) and suggestions regarding each teaching strategy. One way traditional lecture was strongly criticized by many students as dull, boring, less interesting, and teacher centered. It was also disliked because of lack of student role, lack of student teacher interaction and any feedback. One way lecture was also not favored as it was lacking any understanding about prior knowledge of the students, and questions were usually not encouraged. Interactive lectures were strongly favored because of student teacher interaction, two way communication, brain storming, question answer session kept interest in the lecture alive. SGD also got very favorable remarks as being encouraging, having greater student participation, close interaction and chance to discuss queries and solve ambiguities. Students also gave very positive remarks about PBL , advocating its ability to generate discussion, brain storming, close and mandatory participation and sharing of knowledge. PBL was also liked because of deep insight into the subject and applied knowledge. Demonstration on models and specimens was also students' favorite because of visual learning, conceptual learning, retention of knowledge, and seeing the physiopathological process. Details of perceptions and comments about further teaching strategies are given in Table 03.

$S A=$ strongly agree (05), $A=$ Agree (04), Neutral (03), $D=$ disagree (02), $S D=$ strongly disagree $(01)$. Data presented is shown as means, standard deviations, frequencies or percentages of responses for individual teaching methodologies.

\begin{tabular}{|l|c|c|c|c|}
\hline \multicolumn{1}{|c|}{ Teaching Methodology } & Number & Percentage & Male(n=21) & Female(n=56) \\
\hline Interactive Lectures & 22 & $28.57 \%$ & $5(23.8 \%)$ & $17(30.3 \%)$ \\
\hline Small Group Discussions & 16 & $20.78 \%$ & $6(28.6 \%)$ & $10(17.8 \%)$ \\
\hline Laboratory work & 02 & $2.60 \%$ & $1(4.8 \%)$ & $07(12.5 \%)$ \\
\hline Specimens and models & 10 & $12.98 \%$ & $3(14.3 \%)$ & $03(5.4 \%)$ \\
\hline Self-study & 04 & $5.10 \%$ & $01(4.8 \%)$ & $16(28.6 \%)$ \\
\hline Problem based learning & 20 & $25.98 \%$ & $4(19.0)$ & 00 \\
\hline Student's presentations & 01 & $1.30 \%$ & $01(4.8 \%)$ & 00 \\
\hline One-way lecture & 01 & $1.30 \%$ & 00 & $01(1.8)$ \\
\hline Guest speakers & 01 & $1.30 \%$ & $0.8)$ \\
\hline
\end{tabular}




\begin{tabular}{|l|c|c|c|c|c|c|}
\hline Methodology & Mean \pm SD & SD & D & N & A & SA \\
\hline One way lecture & $1.40 \pm 0.712$ & $54(70.1 \%)$ & $17(22.1 \%)$ & $4(5.2 \%)$ & $2(2.6 \%)$ & 00 \\
\hline Interactive lecture & $4.12 \pm 0.778$ & $1(1.3 \%)$ & 00 & $13(16.9 \%)$ & $38(49.4 \%)$ & $25(32.5 \%)$ \\
\hline Small group discussion & $4.26 \pm 0.849$ & $2(2.6 \%)$ & 00 & $08(10.3 \%)$ & $33(42.9 \%)$ & $34(44.2 \%)$ \\
\hline Guest speaker & $3.00 \pm 0.960$ & $07(9.1 \%)$ & $12(15.2 \%)$ & $34(44.2 \%)$ & $22(28.6 \%)$ & $02(2.6 \%)$ \\
\hline Student presentation & $2.91 \pm 1.194$ & $12(15.6 \%)$ & $17(22.1 \%)$ & $19(24.7 \%)$ & $24(31.2 \%)$ & $5(6.5 \%)$ \\
\hline Lab work & $3.73 \pm 0.968$ & $2(2.6 \%)$ & $7(9.1 \%)$ & $16(20.8 \%)$ & $37(48.1 \%)$ & $15(19.5 \%)$ \\
\hline Self study & $3.82 \pm 0.942$ & $3(3.9 \%)$ & $2(2.6 \%)$ & $18(23.4 \%)$ & $37(48.1 \%)$ & $17(22.1 \%)$ \\
\hline Demonstration on models & $4.29 \pm 0.741$ & 00 & $1(1.3 \%)$ & $10(13.0 \%)$ & $32(41.6 \%)$ & $34(44.2 \%)$ \\
\hline Problem based learning & $4.13 \pm 0.978$ & $3(3.9 \%)$ & 00 & $14(18.2 \%)$ & $27(35.1 \%)$ & $33(42.9 \%)$ \\
\hline
\end{tabular}

Table-II. Perception of Medical Students about Teaching Methodologies (Likert Sclae Scoring) $n=77$

\begin{tabular}{|c|c|c|c|}
\hline $\begin{array}{c}\text { Teaching } \\
\text { Methodologies }\end{array}$ & Positive Perceptions & Negative Perceptions & Suggestions \\
\hline One-way lecture & $\begin{array}{l}\text { Relaxing and stress free for } \\
\text { students, }\end{array}$ & $\begin{array}{l}\text { Lenghty, boring, teacher } \\
\text { centered, monotonous, no } \\
\text { student and teacher interaction, } \\
\text {, sleep inducer. taxing for } \\
\text { teachers }\end{array}$ & $\begin{array}{l}\text { Frequency should be } \\
\text { reduced.Duration should be } \\
\text { not more than } 40 \text { minutes. }\end{array}$ \\
\hline Interactive Lectures & $\begin{array}{l}\text { Students particpation, brain } \\
\text { storming, interesting, interactive, } \\
\text { variety of views, questions and } \\
\text { queries answered ,boosts self } \\
\text { confidence }\end{array}$ & $\begin{array}{l}\text { Student must be prepared, } \\
\text { shiness may discourage } \\
\text { students, Interaction creates } \\
\text { stress, lenghty discussions } \\
\text { waste time }\end{array}$ & $\begin{array}{l}\text { Only interested students } \\
\text { who come prepared should } \\
\text { participate. Should always } \\
\text { be concluded in the end }\end{array}$ \\
\hline $\begin{array}{l}\text { Small Group } \\
\text { Discussions }\end{array}$ & $\begin{array}{l}\text { Everyone participates, effective } \\
\text { way to learn,applied knowledge, } \\
\text { discussion clears questions and } \\
\text { queries, very interesting, students } \\
\text { develop close relationship and } \\
\text { rapport }\end{array}$ & $\begin{array}{l}\text { Students may create problems } \\
\text { for others, students with poor } \\
\text { communication skills are at dis } \\
\text { advantage }\end{array}$ & $\begin{array}{l}\text { Should be agenda based. } \\
\text { Not more than } 10 \text { students } \\
\text { in group.teacher should } \\
\text { manage the group.Every } \\
\text { body should participate. }\end{array}$ \\
\hline Laboratory work & $\begin{array}{l}\text { Learning by experience, real life } \\
\text { knowledge, practical knowledge, } \\
\text { excellent retension. }\end{array}$ & $\begin{array}{l}\text { Limited topics supplementery } \\
\text { method with many limitations. }\end{array}$ & $\begin{array}{l}\text { Clinical skills lab should be } \\
\text { established.senior faculty } \\
\text { should also be involved }\end{array}$ \\
\hline $\begin{array}{l}\text { Specimens and } \\
\text { models }\end{array}$ & $\begin{array}{l}\text { Visual learning, Conceptual } \\
\text { and better learning, active } \\
\text { participation, long term retention. }\end{array}$ & $\begin{array}{l}\text { supplementery method with } \\
\text { many limitations.Many models / } \\
\text { manikins not avaiable }\end{array}$ & $\begin{array}{l}\text { More models and } \\
\text { specimens should be } \\
\text { provided. }\end{array}$ \\
\hline Self study & $\begin{array}{l}\text { Easy to focus, active involvement, } \\
\text { easy self assessment, maximun } \\
\text { concentration. }\end{array}$ & $\begin{array}{l}\text { Requires more time, many } \\
\text { distractions, cramming, } \\
\text { no guidanace }\end{array}$ & $\begin{array}{l}\text { Some lectures should be } \\
\text { replaced by self study }\end{array}$ \\
\hline $\begin{array}{l}\text { Problem based } \\
\text { learning }\end{array}$ & $\begin{array}{l}\text { Generates discussion and mental } \\
\text { activity, deep insight and clarity of } \\
\text { concepts, interactive, all students } \\
\text { participate and attain same level of } \\
\text { knowledge, }\end{array}$ & $\begin{array}{l}\text { Time consuming, requires } \\
\text { lot of resources, sometimes } \\
\text { confusing and misleading }\end{array}$ & PBL sessions be increased. \\
\hline $\begin{array}{l}\text { Student's } \\
\text { presentations }\end{array}$ & $\begin{array}{l}\text { Easy going, stress free for } \\
\text { audience, simple topics are easily } \\
\text { conveyed, useful if well prepared. }\end{array}$ & $\begin{array}{l}\text { Students are poorly prepared, } \\
\text { standards varies with students, } \\
\text { inexperience, no discussion. }\end{array}$ & $\begin{array}{l}\text { Students presentations } \\
\text { should be included as CPC, } \\
\text { followed by discussion by } \\
\text { seniors }\end{array}$ \\
\hline Guest speakers & $\begin{array}{l}\text { Good, speaker is motivating, } \\
\text { expert in subject, may convey a } \\
\text { great message, gives inspiration }\end{array}$ & $\begin{array}{l}\text { Protocol oriented, passive } \\
\text { listening, boring, speaker } \\
\text { ignorant of ground realities. }\end{array}$ & $\begin{array}{l}\text { Only very experienced } \\
\text { persons should be invited. } \\
\text { Topic to be foretold. }\end{array}$ \\
\hline \multicolumn{4}{|c|}{ Table-VI. Students Perceptions about Teaching Methodologie } \\
\hline
\end{tabular}




\section{DISCUSSION}

The educational world is acknowledging the importance of understanding the students' different learning style preferences and their role in attaining academic success. ${ }^{1}$

In our study participants were also asked to show their preferences for teaching strategies. Majority of the medical students chose interactive lectures (22, 28.57\%), problem based learning (20, $25.98 \%)$ small group discussions (16, 20.78\%) as their preferred teaching strategies. Students also gave reasons and comments regarding their liking and disliking of various teaching strategies. Focus group discussion was very useful to know their opinions and perceptions about various methods used by medical teachers in present time in various medical colleges in Pakistan. Students strongly criticised traditional one way lecture still being practiced in many medical colleges. Almost all the students had strong reservations against one way lecture reason being lengthy, boring and teacher centred. Students also disliked it as long lecture discourages students' participation and questions and queries are not appropriately answered. Discussions and comments revealed that students preferred those teaching methods which provide active participation thus making them active learners. In FGD discussion it was learnt that students strongly liked those active learning strategies which not only encourage the critical thinking (evaluation, analysis, and interpretation of the information) but also improve the problem solving skills and the decision making thus clarifying their concepts. Students liked interactive lectures, SGD, PBL and DMS. Passive learning formats like one way lectures, guest speakers, student tutorials and self study were mostly ignored and got negative remarks by the majority of the students as they hinder active thinking process thus minimising conceptual and constructivist learning. Our study results are consistent with Costa et al who found that students learn more through interactive lectures and small group discussion. ${ }^{2}$ In our study problem based learning was the second most preferred teaching strategy. This finding is similar to a study by Novak and his colleagues who found that pharmacy students learn best through problem-based learning. ${ }^{3}$ The least preferred teaching strategy identified by medical students was didactic or one-way lecture. This observation of ours is similar with a study by Mukhtar et al which also showed that didactic lecture was least preferred by the students, however the laboratory work $(70 \%)$ was the most preferred, followed by problem based learning, and interactive lectures. ${ }^{4}$ Students in our study significantly preferred small group discussion (26.08\%) and this finding is augmented by another study by Carrier et al. ${ }^{5}$ Rehman et al compared the role of new approaches and methods in understanding and learning capabilities of undergraduate medical students. This study concluded that introduction of PBL, case based sessions, students seminar, quizzes and structured assignments significantly improved the conceptual understanding of the students $(84 \%)$ as compared to students who were taught by traditional methods. ${ }^{6}$ Another study done at King Saud University supports our findings where students taught with discipline based traditional curriculum were compared with students having integrated problem-based learning curriculum. Level of satisfaction was 20\% with traditional methods of teaching as comapred to $80 \%$ with PBL based teaching. Students from both groups strongly liked PBL, clinical skills lab, tutorials, and lectures. ${ }^{7}$ Sawatsky in a study at Pittsburgh has concluded that a structured active teaching format when compared with traditional teaching format, significantly improved resident engagement, knowledge and problem solving skills and required minimal resources. The active teaching format offers an exciting alternative to the standard lecture for residents in medicine and being easy to implement. $^{8}$

\section{CONCLUSION}

Majority liked interactive lectures (28.57\%), problem based learning (25.98\%) and small group discussion $(20.78 \%)$ as their preferred teaching strategies while one way lectures were preferred least. Medical teachers should adopt teaching strategies which have got active participation of students and should employ a variety of modes 
of information transfer which are more student centred.

Copyright@ 25 March, 2016.

\section{REFERENCES}

1. Kember DA, Kwan KP. Lecturers approaches to teaching and their relationship to conceptions of good teaching. Instructional Science 2000 ; 28(5)469490.

2. Buel D. 2001. Classroom Strategies for Interactive Learning. 2nd edition: Newark DE. International Reading Association.

3. Marzano R, Pickering D, Pollock J. Classroom instruction that works. Research based strategies for increasing students Achievements, Alexandria VA:ASCD.

4. Anspaugh D, Ezell G.2007. Teaching Todays health. $8^{\text {th }}$ edition. San Francisco. Pearson Benjamin Cumming Pub.

5. Meeks L, Heit P, Page R.2009. Totally awesome strategies for teaching health. $5^{\text {th }}$ edition.Boston. McGraw Hill.

6. Mustafa AG, Allouh MZ, Mustafa IG, Hoja IM. Anatomy learning styles and strategies among Jordanian and Malaysian medical students: the impact of culture on learning anatom y. Surg Radiol Anat 2013; 35(5):43541.

7. Zapalska, A., \& Dabb, H. Learning styles. Journal of Teaching in International Business, 2002: 13(3/4); 7797.

8. Sternberg R, Grigorenko E, Zhang L. Styles of learning and thinking matter in instruction and assessment. Perspectives on Psychological Science. 2008; 3(6): 486-506.

9. Costa ML, van Rensburg L, Rushton N. Does teaching style matter? A randomised trial of group discussion versus lectures in orthopaedic undergraduate teaching. Med Educ. 2007;41(2):214-7.

10. Novak S, Shah S, Wilson JP, Lawson KA, Salzman RD. Pharmacy students' learning styles before and after a problem-based learning experience. Am J Pharm Educ. 2006;70(4):74.

11. Mukhtar F, Hashmi N, Rauf M.A., Anzar A, Butt K.I., Ahmed M, Abbas $K$. Teaching methodologies; what is the students' perspective? Professional Med J. 2012 ;19(5):597-603.

12. Carrier CA, Newell KJ, Lange AL. Relationship of learning styles to preferences for instructional activities. J Dent Educ. 1982;46(11):652-6.

13. Rehman R, Razi MS, Syed S, Sultan T. Impact of alterations in teaching methodologies on learning capabilities. J Pak Med Assoc Oct-Oct2011;61 (10):9825.

14. Saleh Aal Damegh. Comparison of an integrated problem-based learning curriculum with the traditional discipline-based curriculum in KSA. J Coll Physicians Surg Pak 2005;15:605-8.

15. Sawatsky AP, Berlacher K, Granieri R. Using an ACTIVE teaching format versus a standard lecture format for increasing resident interaction and knowledge achievement during noon conference: a prospective, controlled study. BMC Med Educ. 2014 Jul 1;14:129.

\section{AUTHORSHIP AND CONTRIBUTION DECLARATION}

\begin{tabular}{|c|l|l|l|}
\hline Sr. \# & \multicolumn{1}{|c|}{ Author-s Full Name } & \multicolumn{1}{|c|}{ Contribution to the paper } & Author=s Signature \\
\hline 1 & Dr. Muhammad Asif Bhalli & $\begin{array}{l}\text { Article writing, Data } \\
\text { interpretation } \\
\text { Data collection }\end{array}$ \\
\hline 2 & $\begin{array}{l}\text { Dr. Abdul Sattar } \\
3\end{array}$ & Midhat Asif & Data collection \\
\hline
\end{tabular}

